\title{
Potential of sago hampas for ruminants feed
}

\author{
Heru Ponco Wardono ${ }^{1,2}$, Ali Agus ${ }^{2 *}$, Andriyani Astuti ${ }^{2}$, Nono Ngadiyono ${ }^{3}$, and Bambang \\ Suhartanto ${ }^{2}$ \\ ${ }^{1}$ North Maluku Assesment Institute for Agricultural Technology, Jl. Poros Sofifi-Weda, Kusu, Oba \\ Utara, Tidore Kepulauan 97827, Maluku Utara, Indonesia. \\ ${ }^{2}$ Departemen of Animal Nutrition and Feed Science, Faculty of Animal Science, Universitas Gadjah \\ Mada, Jl. Fauna No. 3, Bulak Sumur, Sleman 55281, Yogyakarta, Indonesia. \\ ${ }^{3}$ Departemen of Animal Production, Faculty of Animal Science, Universitas Gadjah Mada, Jl. Fauna \\ No. 3, Bulak Sumur, Sleman 55281, Yogyakarta, Indonesia.
}

\begin{abstract}
Indonesia has the biggest sago palm forest and cultivation as well as its rich of genetic diversities. Sago planting area in Indonesia has a land area more than 5.5 million hectare ( $85 \%$ of world's sago land area). Currently, the use of sago only focuses on the starch contained in it. Sago hampas is starchy lignocellulosic by-product generated from pith of sago palm after starch extraction. Sago hampas in Indonesia is very abundant, cheaply and not used optimally. Due to its fiber and starch content, sago hampas could be utilized as animal feed especially for ruminants. Sago hampas are limited in their use in making ruminants feed, because it has a high crude fiber and low protein content. Therefore, before the sago hampas is given as ruminant feed, the quality of sago hampas needs to be improve by processing technology. One method of processing sago hampas that can be applied is fermentation. The present study showed that of the utilization of sago hampas had a positive effect on ruminants performance. This review aims to examine the potential of sago hampas as basal feed ruminant as well as efforts to improve their nutritional value.
\end{abstract}

\section{Introduction}

The development of livestock in Indonesia is currently faced with the problem of providing feed, both in terms of quantity and quality. The feed and the nutrients it contains are the most important environmental factors that affect the performance of livestock production [1]. Sources of animal feed can actually be obtained by utilizing agricultural industrial waste which is abundantly available. Optimal utilization of local feed resources is a strategic step in the effort of independence and efficiency of ruminant production in Indonesia [2]. One of the potential local raw materials to be used as a source of ruminant feed is sago hampas.

Sago hampas are waste obtained from the processing or industry of sago flour $[3,4]$. Indonesia has a sago area of around 5.52 million ha or more than $85 \%$ of the world's sago area [5]. The ratio of sago hampas produced in the processing of sago starch is 1:6 [6], meaning that if the production of sago starch from one ripe sago tree weighing $220 \mathrm{~kg}$ can

* Corresponding author: aliagus@ugm.ac.id 
be obtained $1,320 \mathrm{~kg}$ of sago hampas (wet weight) or $396 \mathrm{~kg}$ of dry sago hampas. The largest content in sago hampas is starch, so it has great potential as an energy source for animal feed $[7,8]$.

The problem in the utilization of sago hampas as a feedstuffs is due to the low protein and high crude fiber content [3]. This causes sago hampas to have low digestibility because it is difficult to be degraded by rumen microbes. Low digestibility is a result of the lignification process, where lignocellulose and lignohemicellulose are difficult to separate. Several efforts can be made to improve the quality of sago hampas through processing technology, for example by fermentation. This effort aims to improve the digestibility, palatability, and nutritional value of sago hampas. This review aims to examine the potential of sago hampas when used as ruminant feed and efforts to improve its nutritional quality.

\section{The sago palm}

Sago palm is a native plant of Indonesia, which has high economic value as different parts such as pith, frond, sap, leaf petioles, and even the sago hampas (fibrous residue) are valuable raw material for various industries [9]. Indonesia has an expanse of wild sago crops of around 1.4 million hectares $[6,8,10,11]$, and the largest contribution (more than $85 \%$ ) of the world's sago area [5]. The types of sago plants in Indonesia are very diverse. Researchers suspect that there are more unknown types of sago than those already known. Beccari [11] found 24 and 18 types of sago based on differences in fruit scale and presence of barb. The distribution of sago plants in Indonesia is shown in Table 1.

The main product produced by sago palm is starch. Sago starch is obtained from the extraction or deposition process of sago pith grated and dried. Sago starch contains carbohydrates $(84.70 \%)$ and dietary fiber $(3.69-5.96 \%)$ which is quite high, low of glycemic index (27), and contains starch resistant, non-starch polysaccharides, and short chain of carbohydrates that are very useful for health [12]. Starch production are depends on age, number of leaves and type of sago plant $[13,14]$. The production capacity of sago palm can reach 20-40 tons of dry starch/ha/year [5]. According to Tulalo [13], sago production in the Meranti Islands is $250-300 \mathrm{~kg} /$ tree. In the under good environmental conditions, 15-25 tons/ha of dry sago starch can be produced [15]. If intensive cultivation is carried out with a population of around 100-200 trees/ha, it is estimated that the potential yield of sago starch can increase to 30-60 tons of starch [16].

Sago starch is one of the most widely used palm plant products in the field of bioprocess technology to produce bioethanol, lactic acid and sugar [17]. Besides being able to be used for food ingredients (stabilizers, thickeners and other starch substitutes), it can also be used as an adhesive (paper, textiles, plywood), or converted into other processed products such as liquid sugar, Monosodium Glutamate (MSG), noodles, caramel, sago pearl, and cakes $[9,18]$. The development of liquid sugar to be used as a raw material for industrial needs because the price is cheaper than crystal sugar [9]. Currently, the widely available liquid sugar is supplied from corn raw materials imported from America and South Africa [7]. 
Table 1. Estimated sago area and production by countries

\begin{tabular}{|l|l|r|r|r|}
\hline No. & \multicolumn{1}{|c|}{ Country/Provinces } & \multicolumn{2}{|c|}{ Sago plant area (ha) } & $\begin{array}{c}\text { Projected sago flour } \\
\text { (Tons/year) }\end{array}$ \\
\hline I & Indonesia & $5.519 .637^{*}$ & 1.843 .278 & 2.7364 .170 \\
\hline & Moluccas & $60.000^{*}$ & 41.949 & 629.235 \\
\hline & Sulawesi & $30.000^{*}$ & 45.540 & 683.100 \\
\hline & Kalimantan & $20.000^{*}$ & 8.304 & 45.000 \\
\hline & Sumatera & $30.000^{*}$ & 103.312 & 9.724 .680 \\
\hline & Papua & $4.749 .424^{*}$ & 662.017 & 4.540 \\
\hline & West Papua & $510.213^{*}$ & 981.856 & \\
\hline & Java & & 300 & \\
\hline & Other region & $150.000^{*}$ & & \\
\hline II & Papua New Guinea & & 1.020 .000 & \\
\hline III & Malaysia & & 68.000 & 3.000 \\
\hline IV & Thailand & & 3.000 & \\
\hline V & Philippines & & 5.000 & \\
\hline VI & Other countries & & & \\
\hline
\end{tabular}

Source: Ahmad (2013) and * Bintoro (2019)

\section{Nutrient contents of sago hampas}

The sago waste is divided into two forms, namely sago solid waste (sago hampas) and sago wastewater. Currently, sago hampas has not been utilized properly and has become an environmental problem because it is disposed of as waste $[19,20]$. The high amount of sago waste produced so far has not been used optimally, because it is only allowed to accumulate in the sago processing site, even then it becomes a source of environmental pollution [3].

The comparison between starch and sago hampas produced from processing of sago flour is 1:6 [6]. This means that the potential for wet sago hampas produced is around 2.6 million tons from 432,913 tons of sago starch production in Indonesia in 2017. The feed requirement for each Animal Unit (AU) is 3.32 tons dry matter (DM)/year. Based on this information, Sago hampas if given as a single feed will be able to sufficient the needs of animal feed as much as 234,712 AU/year.

Sago hampas besides having content that is not harmful to animal, it is also cheaper [21]. Research on the physical, chemical characteristics and the use of sago hampas as basal feed has begun to be carried out, but with varying results. Sago hampas originating from West Sulawesi contained crude protein (CP) of 5.23\%, Southeast Sulawesi 1.57\%, Riau Islands $1.94 \%$, Riau $0.18 \%$ and North Sumatra $1.88 \%$ [22]. The diversity of these results is thought to be influenced by differences in species, age of slaughter, ecosystems and processing processes.

Sago hampas is still contains of residual starch [7,8]. Sago hampas contains $60-70 \%$ starch based on dry weight [23]. Sago hampas contained $63.32 \%$ nitrogent free extract (NFE) levels, 54\% total digestible nutrient (TDN) and had fairly good mineral levels, especially phosphorus $(0.58 \%)$ and calcium $(0.56 \%)$ minerals. The largest content of sago hampas is starch which varies between $30-73 \%$ dry weight $[3,24,25]$.

The content of sago pulp is DM 54.03\%, gross energy (GE) 3,912 kcal $/ \mathrm{kg}$, organic matter (OM) 48.75\%, CP 5.02\%, neutral detergent fiber (NDF) $67.78 \%$, and acid detergent fiber (ADF) $43.47 \%$ [26]. Sago hampas contains $30.14 \%$ crude fiber (CF) and $4.37 \%$ crude protein [6]. Sago hampas contains $65.7 \%$ starch, $14.8 \%$ crude fiber, $1 \%$ crude protein, and $4.1 \%$ ash [27]. Sago hampas is a lignocellulosic biomass which contains important components such as starch and cellulose. Sago pulp contains lignocellulose which is rich in cellulose and starch, so it can be used as a carbon source [28]. 


\section{Feed safety based on sago hampas}

Sago hampas are contains three components of the fiber fraction: cellulose, hemi cellulose and lignin [29]. The direct use of sago hampas as an animal feed ingredient is constrained by its high crude fiber content and low protein content [4]. Crude fiber in sago hampas can reach $18 \%$, with 16 to $28 \%$ of which is lignin fiber which is difficult for livestock to digest [3]. Crude fiber is one of the antinutrients that affect the digestibility and palatability of feed [30]. Sago hampas contains lignin residue by $21 \%$, while the cellulose content in it is $20 \%$ and the fritter is extractive substances and ash. Sago hampas contains $29.52 \%$ cellulose. Sago hampas contained starch, cellulose, hemicellulose, pectin and lignin at respectively $58,23,9.2,5.8$, and $3.9 \%$ [31].

Lignin is a non-carbohydrate fraction which is a polyphenolic aromatic polymer with a high molecular weight that is resistant to enzymatic hydrolysis including fermentation by rumen microbes and alkaline substance $[32,33,34]$. Lignin acts as a protective layer on the cellulose-hemicellulose structure of plant tissues to prevent microbial degradation [35], and has an antinutritional role [36]. The complex structure of lignin makes it difficult to degrade so that cellulase, hemicellulase and ligninase enzymes are needed to break it down [37].

Sago hampas based on its nutritional content is estimated to be only able to meet basic life needs, so that for growth, pregnancy and lactation, additional feed is needed to sufficient protein and energy needs [8]. As animal feed, sago hampas are still limited in their use in making animal feed. This happens because sago hampas has a high crude fiber and low protein content. Although the starch content is quite high, the quality of sago hampas needs to be improved by processing technology, one of which is by fermentation. Further processing can make sago hampas as a substitute for feed ingredients for energy sources [38].

\section{Method of increasing the nutrient value of sago hampas}

The basic key in increasing the nutritional value of sago hampas for ruminant feed is how to overcome barriers to the microbial fermentation process in the rumen. The rumen is a complex digestive site in ruminants where various anaerobic microbes live [39]. The rumen contains billions of bacteria, protozoa, fungi, and yeasts that play an important role in the degradation process of feed, both forage and grain [40]. Therefore, the digestive process in the rumen cannot be separated from the role of microorganisms which are very helpful in providing food and energy for livestock. Rumen microorganisms require specific conditions including an anaerobic environment, slightly acidic rumen fluid ( $\mathrm{pH} 6.5$ to 7.0 ), and a supply of ammonia [41]. Rumen microbes are very difficult to digest feed with high crude fiber, especially in breaking lignocellulosic bonds. Processing of feedstuff can be done as an effort to increase the amount of nutrients from feed matter that are absorbed in the digestive tract [33]. This is done through the breakdown of lignocellulosic complex bonds both mechanically/physically [42], chemically and biologically or their combination [43]. However, in terms of efficiency, the selection of the processing method will always be associated with the cost and ease of application of each method so that not all methods are applied.

The method of processing sago hampas that can be applied in the field easily and at low cost is biological treatment by fermentation [38, 44]. The principle of biological treatment by fermentation is the use of ideal microbes that have the ability to degrade lignin [45]. Plant cell walls can be degraded by a combination of bacteria, fungi and protozoa [46]. The contribution of degradation activity by fungi and bacteria is about $80 \%$, while that of protozoa is $20 \%$. The fermentation process occurs due to the performance of various decomposing microbes such as cellulolytic, lignolytic, lipolytic and or non-symbiotic 
nitrogen fixation materials. The fermentation process for foodstuffs produces several advantages, including being able to improve the quality of these foodstuffs both in terms of nutrition and digestibility, while also increasing their storability [47].

The results from the research that we make showed that the fermentation process of sago hampas using a mixture of multimicrobial inoculum by Saus Burger Pakan (SBP) with a dose of $0.5 \%$ and the addition of $0.4 \%$ urea, could increase the nutritional content of sago hampas (Table 2).

Table 2. Nutrient content of sago hampas before and after fermentation

\begin{tabular}{|c|l|r|r|r|r|r|r|r|}
\hline \multirow{2}{*}{ No } & \multirow{2}{*}{$\begin{array}{c}\text { Description of } \\
\text { Feedstuff }\end{array}$} & \multirow{2}{*}{$\begin{array}{c}\text { Dry } \\
\text { Matter }\end{array}$} & & \multicolumn{6}{|c|}{ Percentage based on DM } \\
\cline { 5 - 9 } & & & Ash & $\begin{array}{c}\text { Crude } \\
\text { Protein }\end{array}$ & $\begin{array}{c}\text { Crude } \\
\text { Fat }\end{array}$ & $\begin{array}{c}\text { Crude } \\
\text { Fiber }\end{array}$ & NDF & ADF \\
\hline 1 & SHBF & 89,68 & 11,02 & 3,5 & 1,16 & 38,57 & 84,53 & 65,38 \\
\hline 2 & SHAF 1 & 68,92 & 5,8 & 4,64 & 1,37 & 34,81 & 70,54 & 53,25 \\
\hline 3 & SHAF 2 & 71,89 & 7,86 & 3,64 & 1,18 & 33,24 & 83,79 & 51,02 \\
\hline 4 & SHAF 3 & 69,77 & 7,34 & 3,28 & 0,48 & 33,01 & 65,63 & 49,17 \\
\hline 5 & SHAF 4 & 70,55 & 7,37 & 3,13 & 0,97 & 32,01 & 58,91 & 50,65 \\
\hline 6 & SHAF 5 & 69,15 & 6,66 & 3,54 & 0,16 & 27,84 & 59,8 & 49,33 \\
\hline 7 & SHAF 6 & 82,07 & 7,74 & 3,71 & 1,33 & 31,04 & 68,94 & 48,04 \\
\hline
\end{tabular}

Note : $\quad$ SHBF (Sago Hampas Before Fermentation),

SHAF 1 (Sago Hampas After Fermenting for 12 Hours)

SHAF 2 (Sago Hampas After Fermenting for 24 Hours)

SHAF 3 (Sago Hampas After Fermenting for 48 Hours)

SHAF 4 (Sago Hampas After Fermenting for 72 Hours)

SHAF 5 (Sago Hampas After Fermenting for 120 Hours)

SHAF 6 (Sago Hampas After Fermenting for 168 Hours)

The other research results that have been carried out related to the fermentation treatment of sago hampas show the same results that this method can reduce of crude fiber. Mixing sago hampas with rumen contents (70:30) fermented with Bacillus amyloliquefaciens at a dose of $2 \%$ for 9 days at $40 \mathrm{oC}$ was reported to reduce of crude fiber by $33 \%$ [31]. The fermentation process on sago hampas using a mixture of probiotics as much as $30 \%$ and $30 \%$ urea for 21 days can reduce of crude fiber up to $15.49 \%$ [48]. The use of Aspergillus niger added 5\% urea and 5\% zeolite was able to increase the crude protein content of fermented sago hampas by $15.49 \%$ [3].

\section{Utilization of sago hampas as ruminant feed}

Sago hampas with the nutritional content can be well utilized as ruminant feed [49]. Sago hampas can be used as an energy source because of its high NFE content of $76.51 \%$, but it should not be used as a single feed because of its low CP content [26]. Sago hampas can be given as ruminant feed directly in fresh form (without fermentation) or after going through the fermentation process. Utilization of sago hampas as a single feed or as a mixed stuff in complete feeds should be fermented first so that the nutritional value and digestibility increase.

The addition of fermented sago hampas feed gave a very significant effect on the digestibility of DM until the addition of $50 \%$ of fermented feed was $67.91 \%$ [26]. Feed digestibility is influenced by feed composition, ration composition, feed preparation, animal factors and the amount of feed [50]. Digestibility can be the first measure of the high and low nutritional value of a feedstuffs [51]. The digestibility of a feedstuffs also depends on 
the suitability of the nutrients substances contained in it which is called the association effect [50]. It was reported that the activity of L. Buchnery silage inoculum can improve the digestibility of forage crude fiber in ruminants [52], and is beneficial for the health and production efficiency of ruminants [53]. Silage inoculum containing Saccharomyces had a positive impact on growth performance, rumen fermentation, and digestibility of nutrients in the digestive tract for grower beef cattle [54]. Male Bali cattle receiving bioplus probiotics had higher growth performance than cattle receiving starbio probiotics [55].

Body weight gain is the accumulation of livestock responses to feed consumption, dry matter digestibility of feed, fermentation, metabolism and nutrient absorption [26]. Substitution of field grass with sago hampas up to the level of $45 \%$ with $3 \%$ urea from dry matter of sago hampas did not show significant differences in the efficiency of feed use and body weight gain of Ongole crossbreeds [56]. The use of $40 \%$ sago hampas in the ration did not affect the total or partial volatile fatty acid (VFA) production, acetate/propionate balance and NH3 production [57]. Giving complete feed of fermented sago hampas to Bali cattle up to $75 \%$ can increase the average daily gain (ADG) by $0.47 \mathrm{~kg} / \mathrm{head}$ [26]. Provision of complete wafer rations based on sago hampas of $15-20 \%$ in Aceh cattle resulted in ADG of $0.85-0.87 \mathrm{~kg} / \mathrm{head} /$ day [58]. Complete feed based on fermented sago hampas can be given to cattle up to $50 \%$ of the level of need and still provides a good growth response [26]. Fermented sago hampas of $40 \%$ added with $15 \%$ molasses can be used as a basal feed substitute for grass for goats [59]. The use of fermented sago hampas and tapioca flour as feed for goats can increase growth by $19.65-22.92 \%$ [8].

\section{Conclusion}

Sago hampas based on the nutritional content that they contain have great potential to be used as feedstuffs for ruminants. Indonesia produces 2.6 million tons of sago hampas per year in the form of waste and is a source of environmental pollution. Sago hampas if given as a single feed will be able to sufficient the feed needs of ruminants as much as 234,712 AU/year. Sago hampas as ruminant feed can be given in fresh form and or after going through the fermentation process. Fermented sago hampas can be given as feed in $150 \%$ higher amounts than if it is still in fresh form. Sago hampas should not be used as a single feed, but as a complete feed mixture for ruminants feed in order to produce and reproduce optimally.

Acknowledgement. This research was financial supported by Indonesian Agency for Agricultural Research and Development and Indonesian Agency for National Research and Innovation.

\section{References}

1. Soeparno, Meat Science and Technology (Gadjah Mada University Press, Yogyakarta, 2015)

2. H. Mayulu, Sunarso, C. I. Sutrisno, Sumarsono, Indonesian Agricultural Research and Development J. 29, 1 (2010)

3. L. Muhsafaat, H. A. Sukria, Suryahadi, JIPI, 20, 2 (2015)

4. I. Sangadji, J. Salamena, C. Patty, The nutritive quality of sago waste from oyster mushroom (Pleurotus ostreatus) bio-fermentation yield with different incubation time and urea doses, in $2^{\text {nd }}$ Animal National Seminar, Faculty of Animal Science, Hasanuddin University, Makasar, Indonesia (2016)

5. H.M.H. Bintoro, Potensi dan Produksi Sagu di Indonesia. Bulletin of IPB Agriculture Faculty, Bogor, Indonesia (2019)

6. R. Rianza, D. Rusman, W. Tanwiriah, JIT, 19, 1 (2019) 
7. H.M.H Bintoro, M.Y.J. Purwanto, S. Amarilis, Sagu on Peat Area (IPB Press, Bogor, 2010)

8. K. Simanihuruk, J. Sirait, Sago waste silage with three of additives as basal diet for growing Boerka goat, in Proceedings of the National Seminar on Animal and Veterinery Technology, Indonesia (2017)

9. R.S. Singhal, J.F. Kennedy, S.M. Gopalakrishnan, A. Kaczmarek, C.J. Knill, P.F. Akmar, Carbohydrate Polymers, 72, 1 (2008)

10. A.M.P. Dewi, M.Y. Kusumaningrum, D.N. Edowai, Y. Pranoto, P. Darmadji, Extraction and characterization of cellulose from sago hampas waste, in $8^{\text {nd }}$ SNST Proceesiding, Semarang, Jawa tengah, Indonesia (2017)

11. M. Flach, Sago Palm (Metroxylon sagu Rottb) (IPGRI, Rome, Italy, 1997)

12. W.W.K. Tirta, P.N. Indrianti, R. Ekafitri, Pangan J. 22, 1 (2013)

13. M.A. Tulalo, H. Novarianto, B. Palma. 14, 1 (2013)

14. Maherawati, R.B. Lestari, Haryadi, Agritech. 31, 1 (2011)

15. T.H. Rasyid, Y. Kusumawaty, S. Hadi, in IOP Conf. Series: Earth and Environmental Science, Indonesia (2020)

16. A.D. Santoso, JRL. 10, 2 (2017)

17. W.K.L. Lim, H.H. Chung, H. Hussain, K. Bujang, Pertanika J. Trop. Agric. Sc, 42, 2 (2019)

18. E.Y. Purwani, Widaningrum, R. Thahir, Muslich, Indonesian Journal of Agricultural Science. 7, 1 (2006)

19. B.M.W. Tiro, P.A. Beding, Y. Baliadi, The utilization of sago waste as cattle feed. In IOP Conf. Series: Environ Earth Sci. Indonesia (2018)

20. M.I. Rosli, M.A.N. Abdul, S.T. Mohd, P.C. Lee, Energies. 11, 9 (2018)

21. S. Indrayati, Y.M. Naru, Periadnadi, Nurmiati, Bibiet Journal, 2, 2 (2017)

22. B. Dwinarto, E. Bogassara, A.A. Wida, Sunarwan, I. Amarudin, Test Results of Animal Feed Ingredients and Forages (BPMSP, Bekasi, Jawa Barat, 2013)

23. S. Vickineswary, Y.L. Shim, J.J. Thambirajah, N. Blakebrough, Resource and Conservation Recycling, 11, 1 (1994)

24. D.S.A. Adeni, K.B. Bujang, M.A. Hasan, Azis, BioMed Res Int, 1 (2013).

25. J.C. Lai, W.A. Rahman, W.Y. Toh, Industrial Crops and Products, 45 (2013)

26. D. Sisriyenni, A. Simanjuntak, T. Adelina, Potential and utilization of fermented sago byproduct as cattle feed in Meranti Island District, in Proceedings of the National Seminar on Animal and Veterinery Technology, Indonesia (2017)

27. S. Abd-aziz, J. Biosci. Bioeng. 94 (2002).

28. L.J. Kiat, Preparation and Characterization of Carboxymethyl Sago Waste and Its Hydro gel (Thesis, UPM, Malaysia, 2006)

29. A. Paterson, Biodegradation of Lignin and Cellulosic Materials, In: Animal Production and Health Division, FAO, Biotechnology for Livestock Production, Plenum Press, 1989)

30. H.R. Enami, FAS, 6, 1 (2011)

31. Wizna, A. Hafil, R. Yose, D. Abdi, K. Putu, Pak J Nutr. 7, 2 (2008)

32. A. Hatakka, Biodegration of Lignin (University of Helsinki, Viikki Biocenter, Department of Applied Chemistry dan Microbiology, Helsinki, 2000)

33. P. McDonald, R.A. Edwards, J.F.D. Greenhalgh, C.A. Morgan, L.A. Sinclair, R.G. Wilkinson, Animal Nutrition (7th Edition, Pearson, Harlow, London, 2010)

34. S.H. Ghaffar, M. Fan, International Journal of Adhesion \& Adhesives, 48 (2014)

35. R. Vanholme, B. Demedts, K. Morreel, J. Ralph, W. Boerjan, Plant Physiology, 153, 3 (2010)

36. M. Antongiovanni, C. Sargentini. 1991, Variability in Chemical Composition of Straws. Options Mediterraneennes, in Seminaires Mediterraneens, A (1991) 
37. J.B. Schiere, M.N.M. Ibrahim, Feeding of urea ammonia treated rice straw: $A$ compilation of miscellaneous reports produced by the straw utilization project, Pudoc, Wageningen, SriLanka (1989)

38. B. Seglar, Fermentation analysis and silage quality testing, in Proceedings of the Minnesota Dairy Health Conference, University of Minnesota (2003)

39. I. G. L.O. Cakra, Ruminologi. Fakulty of Animal Science, Udayana University, Denpasar (2016)

40. J. B. Hall, S. Silver, Digestive System of the Cow, Virginia Cooperative Extension. Publication 400-010,1-4 (2009)

41. H. Mayulu, M. Sunarso, Christiyanto, F. Ballo, Internat. J. of Sci. and Eng, 4, 2: 8691, DOI: 10.12777/ijse.4.2.2013.86-91 (2013)

42. M. Sarwar, M. A. Khan, M. Nisa, Australian Journal of Agricultural Research, 55, 223-228 (2004)

43. P. T. Doyle, C. Devendra, G. R. Pearce, Rice straw as a feed for ruminants. International Development Program of Australian University and Colleges Limited (IDP), Canberra, Australia (1996)44. Y. Zakaria, C.I. Novita, Samadi, Agripet 13, 1 (2013)

45. J.X. Liu, E.R. Orskov, Animal Feed Science and Technology, 88 (2000)

46. J. Dijkstra, S. Tamminga. Br. J. Nutr. 74, 5 (1995)

47. N. Sanlier, B.G. Busra, C.S. Aybuke, Food Sci Nutr., 25, 1 (2017)

48. H.T. Uhi, Jurnal Ilmu Ternak, 7, 1 (2007)

49. K. Simanihuruk, Antonius, J. Sirait, The use of sago waste as component of complete feed for growing Boerka goat, in National Seminar on Animal Science and Veterinary Technology, Indonesia (2013)

50. D. A. Tillman, S, Reksohadiprodjo, H. Hartadi, S. Prawirokusumo, S. Lebdosoekojo, Ilmu Makanan Ternak Dasar (Gadjah Mada University Press, Yogyakarta, 1998)

51. A. Astuti, A. Agus, S.P.S. Budhi, Bulletin of Animal Science, 33, 2 (2009)52.

W. Addah, J. Baah, E.K. Okine, T.A. McAllister, J. Anim. Sci. 90 (2015)

53. L. Duniere, L. Jin, B. Smiley, M. Qi, W. Rutherford, Y. Wang, T. Mcallister, J. Anim. Sci. 93 (2015)

54. J. Nair, S. Xu, B. Smiley, H. Yang, T.A. McAllister, Y. Wang, J Anim Sci. 97, 12 (2019)

55. H.H. Marawali, S. Ratnawaty, D. Kana Hau, J. Nulik, An Assesment of Body Weight Changes of Beef Cattle and its Income on Farm Level in North Central Timor Regency of East Nusa Tenggara Province, in National Seminar on Animal Science and Veterinary Technology, Indonesia (2004)

56. Pantjawidjaja, S.P. Pongsapan, F.K. Tandilinting, Animal Science, 1 (1984)

57. E. Nurkurnia, The Result of Rumen Fermentation of Female Kacang Goats with the Provision of Several Levels of Sago Waste (Metroxylon sp) in the feed (Essay, IPB Bogor, Indonesia, 1989)

58. M. Daud, Zulfan, Arismawan. 2017. Palatability test of feed product sago waste based wafer complete ration for Aceh beef cattle, in Animal National Seminar, Faculty of Animal Science, Hasanuddin University, Makasar (2017) 59. K.

Simanihuruk, A. Chaniago, J. Sirait, Sago waste silage as basal diet for growing goats, in National Seminar on Animal Science and Veterinary Technology, Indonesia (2011)

60. M. Ahmad, Engineering and Information Technology. 4, 3: 15-17 (2013) 